\title{
Putting our money to good use: Can we attract more passengers without increasing subsidies?
}

\author{
Johan Holmgren
}

Linköping University Post Print

\section{Tweet}

N.B.: When citing this work, cite the original article.

Original Publication:

Johan Holmgren , Putting our money to good use: Can we attract more passengers without increasing subsidies?, 2010, Research in Transportation Economics, (29), 1, 256-260.

http://dx.doi.org/10.1016/j.retrec.2010.07.032

Copyright: Elsevier

http://www.elsevier.com/

Postprint available at: Linköping University Electronic Press

http://urn.kb.se/resolve?urn=urn:nbn:se:liu:diva-60014 


\title{
Putting our money to good use: Can we attract more passengers without increasing subsidies?
}

\author{
Johan Holmgren \\ Department of Management and Engineering, Linköping University \\ Linköping, SE-58183, Sweden \\ johan.holmgren@liu.se, Phone: +46 13 282521, Fax: +4613281101
}

Keywords: Public transport, Demand, Supply, Fare, Subsidies, Maximization, Elasticity

\begin{abstract}
This paper evaluates the policy of Swedish public transport authorities, determining whether the number of trips on local public transport could have been increased without increasing subsidies. Based on annual data from Swedish counties, the evaluation found that between 1986 and 2001 public transport fares exceeded the passenger-maximizing fare most of the time in all but two counties, the average deviation being 1-215\%. Evaluating the alternative, passenger-maximizing policy, including both fare and service changes for 2001, demonstrated that demand for local public transport in Swedish counties could have been increased by $0-178 \%$ without increasing subsidies. Aggregated, this represents a $2.3 \%$ increase in the number of trips on local public transport in Sweden.
\end{abstract}

\section{Introduction}

In times of increasing environmental problems, and when cities are being overwhelmed by traffic congestion, public transport is often seen as part of the solution. Despite this, the private car has long time gained market shares at the expense of public transport in most urban areas in Europe.

At a strategic level, the transport suppliers' primary means of affecting demand is through changes in price and service levels. From a policy viewpoint, the balance between fare and service level (in combination with subsidy level) constitutes the fundamental strategic decision. ${ }^{1}$ Since demand for public funds appears limitless and politicians are hard pressed not to raise taxes or divert money from other deserving needs, such as education, healthcare, childcare, or eldercare, it is important to evaluate whether current public transport subsidies are being used optimally. This paper evaluates the policy of Swedish transport authorities, determining whether the number

\footnotetext{
${ }^{1}$ From a broader perspective, the question of congestion charges is also crucial to the development of public transport demand.
} 
of trips on local public transport could have been increased without increasing subsidies.

The objective evaluated here is maximizing the number of trips made under current subsidy levels. ${ }^{2}$ Privately owned producers would probably try to maximize their profits unless regulated. Since public transport in Sweden is publicly controlled and heavily subsidized, the producer's goal is should arguably be social welfare maximization, but trip maximization (or passenger kilometres) has the advantage of simplicity. It is more easily understood by decision-makers and easier to convey to the public. The welfare loss from implementing passenger maximization instead of welfare optimization is not necessarily great, so it would likely represent an improvement over the present situation. For more extensive discussion of the effects of different management objectives, see Bös (1978), Glaister and Collings (1978), Nash (1978), and Webster and Bly (1980).

The present study uses annual data from the urban areas of Sweden's 26 counties from 1986 to 2001. Data are aggregated at a county level, so the figures from each county contain information on several towns. Due to changes in the county structure and missing data, the panel is unbalanced and the total number of usable observations is 346. The data concerning patronage, vehicle-kilometres, costs, and fares are supplied by the Swedish Public Transport Association (Svenska Lokaltrafikföreningen, SLTF), ${ }^{3}$ to which local transport authorities report several key statistics. ${ }^{4}$ Before 1986, the data were not reported in the same way, so it is impossible to convert the series to be compatible, and after 2001 local and regional travel are no longer reported separately. Data on income, population, and car ownership were obtained from Statistics Sweden (SCB).

The next section presents the data on variables previously found to affect public transport demand and briefly discusses the development of local public transport in Sweden over the studied period. Then the criterion for maximizing the number of trips in terms of the relationship between fare and service elasticities is presented. A demand function is estimated from the data, and the elasticities are used to evaluate the performance of the public transport system in relation to passenger maximization. The last section summarizes the results and presents some final remarks.

\section{Public transport in Sweden ${ }^{5}$}

Between 1986 and 2001, the total number of local trips on public transport in Sweden increased by $18.5 \%$, a figure sometimes used to portray public transport as a success story. However, this is misleading for two reasons. The uncharacteristic development of the county of Stockholm (including the Swedish capital) obscures that patronage fell in

\footnotetext{
2 This is interchangeably referred to as trip maximization, demand maximization, passenger maximization, and patronage maximization; the terms "optimum" or "optimal" are used to refer to the situation in which this objective is fulfilled.

${ }^{3}$ This body is currently named Svensk Kollektivtrafik.

${ }^{4}$ The responsibility for public transport statistics has now been transferred from SLTF to the Swedish Institute for Transport and Communications Analysis (SIKA).

${ }^{5}$ All data cited in this section were obtained from SLTF and Statistics Sweden.
} 
most other counties. Excluding Stockholm, the total number of trips actually fell by $27.5 \%$. Looking at the development of per capita figures, the total number of trips per capita fell by $5.2 \%$ over the period in question, and excluding Stockholm, by $31 \%$.

The demand underlying these aggregates differs immensely between counties: in 2001, 634 million trips were made in Stockholm, while only 280 thousand trips were made in the county of Gotland. Table 1 shows the heterogeneity of demand in terms of average per capita figures as well as the percentage change in number of trips per capita over the period in question. ${ }^{6}$

\section{Place table 1 about here}

Stockholm's unique position is further underlined by these figures, as not only is the number of trips per capita by far the highest there, but there was also an increase in demand over the observed period. The only other counties where this occurred are Blekinge, Västernorrland, and Skåne (1999-2001). In all other counties, the number of trips per capita has fallen since 1986.

Unsurprisingly, there is also considerable variation in service levels. Table 2 shows these variations in terms of average number of vehicle-kilometres per $\mathrm{km}^{2}$ as well as the percentage change over the observed period. Stockholm again stands out, this time as the region having the highest level of public transport service.

\section{Place table 2 about here}

Measured in revenue per trip, fares in 2001 ranged from SEK 1.96 in the county of Västernorrland to SEK 20.55 in Kalmar, making the monetary part of the generalized cost vary considerably. ${ }^{7}$ With a $200 \%$ increase in real fares over the studied period, the county of Kalmar also exhibits one of the most striking developments in fares, surpassed only by Jämtland where fares increased by $251 \%$. At the other end of the scale, Blekinge and Västernorrland lowered their fares substantially (66\% and 73\%, respectively). Interestingly, these two counties also are among the few where patronage increased. County averages and changes are shown in Table 3.

When it comes to income and car ownership, the variation between counties is less than for the other variables. Gotland, together with Dalarna, Norrbotten, and Värmland, all

\footnotetext{
${ }^{6}$ In most counties, all trips by public transport are made by bus, but in Stockholm the figures also include trips by underground while in Göteborg and Östergötland travel by tram is included. The same applies to the supply figures discussed below.

${ }^{7}$ All monetary figures (i.e. fares, income, and costs) are expressed in real terms using 2000 as the base year.
} 
exhibited car ownership levels exceeding 0.5 cars per capita, i.e. $0.53,0.52,0.5$, and 0.5, respectively, in 2001, while Stockholm was the only county with car ownership below 0.4 (i.e. 0.39) cars per capita. Average car ownership levels as well as income are shown in Table 4.

\section{Place table 3 about here}

The variation in income is also relatively small between most counties, although average income in Stockholm exceeded the average in Gotland by $40 \%$ in 2001 . Over the 1986-2001 period, the increase in average real income varied between $20 \%$ (Västerbotten and Norrbotten) and 28\% (Stockholm).

\section{Place table 4 about here}

\section{Getting the most for our money}

This section derives the conditions for passenger maximization, in terms of fare and service (supply of vehicle-kilometres) elasticity. In general, the number of trips on public transport $(\mathrm{Q})$ is a function of the costs associated with the use of different modes of transport so that ${ }^{8}$

$Q=f\left(G C_{1}, G C_{2}, \ldots \ldots, G C_{n}\right)$

where $G C_{\mathrm{n}}$ refers to the generalized cost of transport mode $n$. Generalized cost is, as usual, the sum of walking time cost $(W)$, waiting time cost $(T)$, in-vehicle time cost $(J)$, and fare $(F)$. The transport provider must operate under the constraint that revenue plus subsidies equals cost, i.e. the budget constraint is

$$
Q \cdot F+S=C
$$

where $S$ is the subsidy and $C$ the total cost of operations.

\footnotetext{
${ }^{8}$ Public transport demand is also affected by other variables, most importantly, income and car availability, which are omitted at this stage since this section focuses on factors within the public transport authorities' control.
} 
Since generalized cost is affected by the supply of vehicle-kilometres (V) through its effect on waiting time and route density, the public transport provider can influence demand through fare and vehicle-kilometres. From the provider's perspective, the demand function can therefore be expressed as:

$$
Q=Q(F, V)
$$

Conditions for patronage maximization could be derived by differentiating the Lagrangian, as follows:

$$
L=Q(F, V)+\lambda \cdot(C(V)-Q(F, V) \cdot F-S)
$$

where $C$ is assumed to be a function of $V$. The first-order conditions are therefore

$$
\begin{aligned}
& \frac{\partial L}{\partial F}=\frac{\partial Q}{\partial F}-\lambda \cdot\left(\frac{\partial Q}{\partial F} \cdot F+Q\right)=0 \\
& \frac{\partial L}{\partial V}=\frac{\partial Q}{\partial V}+\lambda \cdot\left(\frac{\partial C}{\partial V}-\frac{\partial Q}{\partial V} \cdot F\right)=0 \\
& \frac{\partial L}{\partial \lambda}=C-Q \cdot F-S=0
\end{aligned}
$$

Combining the two first gives

$$
\frac{\frac{\partial Q}{\partial F}}{\frac{\partial Q}{\partial F} \cdot F+Q}=-\frac{\frac{\partial Q}{\partial V}}{\frac{\partial C}{\partial V}-F \cdot \frac{\partial Q}{\partial V}}
$$

Multiplying the numerator and denominator of the left side of expression (3) by $\frac{F}{Q}$ and, similarly, the right side by $\frac{V}{Q}$ results in 
$\frac{e_{F}}{F \cdot\left(e_{F}+1\right)}=\frac{e_{V}}{e_{V} \cdot F-\frac{V}{Q} \cdot \frac{\partial C}{\partial V}}$

where $e_{F}$ is the elasticity of demand with respect to fare and $e_{F}$ is the elasticity of demand with respect to vehicle-kilometres. ${ }^{9}$ This can be expressed as

$\frac{e_{F}}{e_{V}}=-\frac{F \cdot Q}{V \cdot \frac{\partial C}{\partial V}}$

Defining $y$ as the cost-revenue ratio (i.e. $y=\frac{C}{Q \cdot F}$ ) and $x$ as the elasticity of costs with respect to $V^{10}$, (4) can be expressed as

$\frac{e_{F}}{e_{V}}=-\frac{1}{y \cdot x}$

Assuming that in the long run there are no fixed costs (i.e. $x=1$ ), the optimum relationship between fare and service elasticity (with unchanged subsidy) can be expressed as ${ }^{11}$

$e_{F}=-\frac{1}{y} \cdot e_{V}$

${ }^{9} e_{F}=\frac{\partial Q}{\partial F} \cdot \frac{F}{Q}$ and $e_{V}=\frac{\partial Q}{\partial V} \cdot \frac{V}{Q}$

${ }^{10} x=\frac{\partial C}{\partial V} \cdot \frac{V}{C}$

${ }^{11}$ Webster and Bly (1980) achieve the same result using a model in which GC is minimized. 


\section{Demand model and empirical results}

To obtain the fare and service elasticities needed for evaluation, a demand model is estimated using the data described above.

Nelson (1972), among others, argues that the price elasticity $\left(e_{\mathrm{F}}\right)$ should increase with fares. The rationale for this assumption is that increased fares at low fare levels should increase revenue; this will be true until the elasticity is one, after which fare increases will result in declining revenue. A commonly used (see Holmgren, 2007) functional form fulfilling this requirement is the semi-logarithmic model (e.g. Frankena, 1978; Dargay and Hanly, 2002). Assuming a semi-logarithmic functional form, the demand function can be expressed as

$$
\ln D_{i, t}=\alpha_{1} \cdot F_{i, t}+\alpha_{2} \cdot \ln \left(\frac{V}{A}\right)_{i, t}+\alpha_{3} \cdot \ln B_{i, t}+\alpha_{4} \cdot \ln Y_{i, t}+\alpha_{5} \cdot \ln P_{i, t}^{\text {Petrol }}+\delta_{i}+\varepsilon_{i, t}
$$

where $D_{\mathrm{i}, \mathrm{t}}$ is number of trips per capita in county $i$ in year $t, A$ is the area of operations, $B$ is car ownership, and $P^{\mathrm{Petrol}}$ is the price of petrol. The model contains county specific effects $\left(\delta_{i}\right)$ to account for time-invariant factors not captured by the other variables.

Table 5 shows the results of the estimation (using the fixed effects (FE) estimator ${ }^{12}$ ) of the demand equation (price of petrol is removed since it was not significant at any reasonable level of significance $\left.{ }^{13}\right)$.

\section{Place table 5 about here}

Evaluated at the 2001 fare levels, the elasticities with respect to fare range from -0.12 in Blekinge to -1.22 in Kalmar, with an average elasticity of -0.49 . The results appear to be in line with those obtained in previous demand studies. See Goodwin (1992), Oum et al. (1992), Balcombe et al. (2004), Holmgren (2007), and Hensher (2008) for overviews and discussions of previous results. The high elasticity found in Kalmar indicates that lower fares would actually have resulted in higher revenues, which could then have been used to increase services.

\footnotetext{
${ }^{12}$ See Baltagi (2001), Hsiao (2003), or Wooldridge (2002) for further discussion of panel data estimation.

${ }^{13} P$-value $=0.37$.
} 


\subsection{Passenger-maximizing fares}

Using the demand model (7), $e_{F}=\alpha_{1} \cdot F$ while the elasticities with respect to the other variables are constants (e.g. $e_{V}=\alpha_{2}$ ). The optimal fare can therefore be calculated as follows:

$$
F^{o p t}=-\frac{1}{y} \cdot \frac{\alpha_{2}}{\alpha_{1}}
$$

Table 6 shows the average deviation (in percent) from the optimal fare over the 19862001 period using the results from Table 5 in equation (8). It can be seen that in all but two counties, fares were on average higher than the optimal fare and that in most cases the deviations were quite large. This would indicate that Swedish decision-makers have preferred to over-provide service at a given subsidy level. Although not the topic of this paper, at least part of this overcharging is arguably due to relatively high off-peak prices. It has been demonstrated that significant welfare gains could be achieved in Swedish towns if a two-part tariff were applied. (Ljungberg, 2007; Holmgren et al., 2008). This might also be due to the desire to provide at least minimum service on routes where demand is low, to serve those who cannot travel by other modes. Such a policy would require higher prices (or subsidy) to be financed.

\section{Place table 6 about here}

\subsection{Examining the results of implementing a trip-maximizing policy}

To indicate what a change in policy towards passenger maximization would imply, the year 2001 is used as an example. Table 7 shows the fares in each county, the optimal fare calculated as described above, and the fare change in percent. In most (i.e. 13 of 19) counties, the alternative policy would have meant lower fares, in some cases by quite substantial amounts.

\section{Place table 7 about here}

The most substantial change is called for in Kalmar, which is not surprising given the high fare in that county.

To keep the subsidies unchanged, the fare changes would also require changes in service level (i.e. supply of vehicle-kilometres). The change in vehicle-kilometres associated with the fare change under the budget constraint (1) can be found through implicit differentiation of the constraint, as follows: 


$$
\frac{d V}{d F}=-\frac{Q-F \cdot \frac{\partial Q}{\partial F}}{F \cdot \frac{\partial Q}{\partial V}-\frac{\partial C}{\partial V}}
$$

Equation (9) can be restated in elasticity form so that

$$
e_{V F}=-\frac{1-e_{F}}{\frac{\partial C}{\partial V}-\frac{V}{Q \cdot F}}
$$

The elasticity, $\mathrm{e}_{\mathrm{VF}}$, is the percentage change in $V$ required when $F$ changes by $1 \%$ to stay within the budget constraint. This expression can be used to approximate how much supply would have to be changed following the fare change recommended above. ${ }^{14}$ Table 8 shows the required change in vehicle-kilometres associated with the suggested fare change. ${ }^{15}$

\section{Place table 8 about here}

One of the most interesting things seen from Table 8 is that in the county of Kalmar, service can be increased despite fares being lowered substantially (80\%), as seen in Table 7. This would indicate that the fare levels in Kalmar were set so high that a decrease would have resulted in increased revenue due to increased patronage (i.e. $\left.e_{F}>1\right)$. The situation in Kalmar differs from those in the other counties where service increases are indicated, i.e. Östergötland, Kronoberg, Blekinge, Västernorrland, Skåne, and Västra Götaland. In those cases, increased service would be enabled by a fare increase.

The suggested fare change and the associated change in service are then used in the demand function to calculate how much higher demand would have been in 2001 under such a policy. Table 9 shows the suggested fare and service changes and the estimated changes in patronage.

\section{Place table 9 about here}

\footnotetext{
${ }^{14}$ Since equation (10) expresses a point elasticity, its accuracy diminishes with the size of the fare change.

15 The average cost per vehicle-kilometre in each county is used in the calculation as $\partial \mathrm{C} / \partial \mathrm{V}$. Fares, vehiclekilometres, and number of trips at the starting point (before change), i.e. the year 2001, are used in the calculations.
} 
From Table 9 it can be seen that the gains in patronage vary substantially between counties, ranging from $0.04 \%$ in Örebro to $178 \%$ in Kalmar. This indicates that, although some counties are actually operating under close to passenger-maximizing conditions, some are far from them. At an aggregated level, the alternative policy would have resulted in $2.3 \%$ more trips on local public transport or $7.2 \%$ more outside Stockholm, Skåne, and Västra Götaland (the counties containing the three largest cities in Sweden). ${ }^{16}$

\section{Conclusions}

The difficulty of local public transport competing with the private car for market share in combination with rising costs raises the question of whether public transport subsidies are being used efficiently. This paper evaluated whether the balance between fares and service could have been changed to attract more passengers to local public transport.

The findings show that average fares exceeded the passenger-maximizing fare over the investigated period, indicating that Swedish decision-makers overemphasized service over low fares. This is possibly because they were striving to sustain at least minimum service levels in low-demand areas, in combination with unwillingness to differentiate between peak and off-peak fares.

As an example, it was demonstrated that charging passenger-maximizing fares in 2001 (with unchanged subsidies) would have resulted in lower fares and lower service (in terms of vehicle-kilometres) in most counties, although there are counties where the opposite would have occurred. Such changes would have increased the aggregated number of trips by $2.3 \%$, but with substantial variation between counties.

Although the results must be taken as rough estimates based on a high level of aggregation, they can nevertheless be seen as indicating considerable potential for improvement.

\section{References}

Balcombe, R., Mackett, R., Paully, N., Preston, J., Shires, J., Titheridge, H., Wardman, M., \& White, P. (2004). The demand for public transport: A practical guide. Report TRL593. Wokingham, UK: TRL.

Baltagi, B. (2001). Econometric analysis of panel data. New York: John Wiley \& Sons. Bös, D. (1978). Distributional effects of maximisation of passenger miles. Journal of Transport Economics and Policy, 12, 322-329

Dargay, J., \& Hanly, M. (2002). The demand for local bus services in England. Journal of Transport Economics and Policy, 36, 73-91

\footnotetext{
${ }^{16}$ A level of 2.3 percent might not seem like much, but in terms of number of trips, this increase represents $21,034,411$ trips in the counties listed in the table.
} 
Frankena, M. W. (1978). The demand for urban bus transit in Canada. Journal of Transport Economics and Policy, 12, 280-303

Glaister, S., \& Collings, J. J. (1978). Maximisation of passenger miles in theory and Practice. Journal of Transport Economics and Policy, 12, 304-321

Goodwin, P. B. (1992). A review of new demand elasticities with special reference to short and long run effects of price changes. Journal of Transport Economics and Policy, 26, 155-169

Hensher, D. (2008). Assessing systematic sources of variation in public transport elasticities: some comparative warnings. Transportation Research Part A, 42, $1031-1042$

Holmgren, J. (2007). Meta-analysis of public transport demand. Transportation Research Part A, 41, 1021-1035

Holmgren, J., Jansson, J. O., \& Ljungberg, A. (2008), Public transport in towns inevitably on the decline? Research in Transportation Economics, 23, 65-74

Hsiao, C. (2003). Analysis of panel data. Cambridge, UK: Cambridge University Press. Ljungberg, A. (2007). Lokal kollektivtrafik på samhällsekonomisk grundval. Ph.D. thesis. Linköping, Sweden: IEI, Linköping University

Nash, C. A. (1978). Management objectives, fares, and service levels in bus transport. Journal of Transport Economics and Policy, 12, 70-85

Nelson, G. (1972). An econometric model of urban bus transit operations. Ph.D. thesis. Houston, TX: Rice University.

Oum, T. H., Waters, W. G., \& Yong, J. S. (1992). Concepts of price elasticities of transport demand and recent empirical estimates. Journal of Transport Economics and Policy, 26,139-154

Webster, F. V., \& Bly, P. H. (1980). The demand for public transport. Report of the international collaborative study of the factors affecting public transport patronage. Wokingham, UK: TRL.

Wooldridge, J. M. (2002). Econometric analysis of cross section and panel data. Cambridge, MA: The MIT Press. 
Table 1 Average number of trips per capita in urban areas for the 1986-2001 period in Swedish counties and percentage change between 1986 and 2001.

\begin{tabular}{|c|c|c|c|c|c|}
\hline County & $\begin{array}{l}\text { Trips per } \\
\text { capita }\end{array}$ & $\Delta \%$ & County & $\begin{array}{l}\text { Trips per } \\
\text { capita }\end{array}$ & $\Delta \%$ \\
\hline Stockholm & 350 & 8 & Älvsborg* & 32 & -29 \\
\hline Uppland & 72 & -47 & Skaraborg* & 19 & -39 \\
\hline Södermanland & 22 & -28 & Värmland & 25 & -32 \\
\hline Östergötland & 71 & -42 & Örebro & 36 & -36 \\
\hline Jönköping & 46 & -31 & Västmanland & 33 & -41 \\
\hline Kronoberg & 19 & -17 & Dalarna & 32 & -45 \\
\hline Kalmar & 10 & -79 & Gävleborg & 35 & -32 \\
\hline Gotland & 11 & -44 & Västernorrland & 29 & 20 \\
\hline Blekinge & 24 & 4 & Jämtland & 128 & -72 \\
\hline Kristianstad* $^{*}$ & 12 & -23 & Västerbotten & 30 & -16 \\
\hline Malmöhus* & 66 & -32 & Norrbotten & 28 & -37 \\
\hline Halland & 25 & -56 & Skåne* & 39 & 15 \\
\hline Göteborg/Bohus* & 183 & -20 & Västra Götaland & 108 & -0.5 \\
\hline
\end{tabular}

* In 1997, the Skåne and Västra Götaland regions were formed, the former from Kristianstad and Malmöhus and the latter from Göteborg/Bohus, Älvsborg, and Skaraborg. The figures for these counties therefore cover the years 1986-1997, while the figures from Skåne and Västra Götaland cover the years 1999-2001. 
Table 2. Average number of vehicle-kilometres per $\mathrm{km}^{2}$ in urban areas for the 19862001 period in Swedish counties and percentage change between 1986 and 2001

\begin{tabular}{|c|c|c|c|c|c|}
\hline County & VKM//km² & $\Delta \%$ & County & VKM/ $\mathbf{k m}^{2}$ & $\Delta \%$ \\
\hline Stockholm & 3227 & 12 & Älvsborg ${ }^{*}$ & \begin{tabular}{|l|}
174 \\
\end{tabular} & $-12^{*}$ \\
\hline Uppland & 620 & -30 & Skaraborg* & 110 & $-23^{*}$ \\
\hline Södermanland & 205 & 4 & Värmland & 121 & -9 \\
\hline Östergötland & 433 & -16 & Örebro & 161 & -4 \\
\hline Jönköping & 318 & -20 & Västmanland & 249 & -5 \\
\hline Kronoberg & 112 & 10 & Dalarna & 90 & -10 \\
\hline Kalmar & 139 & -34 & Gävleborg & 165 & -2 \\
\hline Gotland & 80 & -7 & Västernorrland & 157 & 1 \\
\hline Blekinge & 160 & 9 & Jämtland & 352 & -42 \\
\hline Kristianstad $^{*}$ & 62 & $-42^{*}$ & Västerbotten & 163 & -11 \\
\hline Malmöhus* & 547 & $-18^{*}$ & Norrbotten & 200 & 6 \\
\hline Halland & 154 & -4 & Skåne ${ }^{*}$ & 322 & $14^{*}$ \\
\hline Göteborg/Bohus* & 895 & $-26^{*}$ & Västra Götaland* & 457 & $5^{*}$ \\
\hline
\end{tabular}

* In 1997, the Skåne and Västra Götaland regions were formed, the former from Kristianstad and Malmöhus and the latter from Göteborg/Bohus, Älvsborg, and Skaraborg. The figures for these counties therefore cover the years 1986-1997, while the figures for Skåne and Västra Götaland cover the years 1999-2001. 
Table 3. Average public transport fares in SEK for urban traffic for the 1986-2001 period in Swedish counties and the change between 1986 and 2001.

\begin{tabular}{|l|c|c|l|c|c|}
\hline \multicolumn{1}{|c|}{ County } & Fare & Change \% & \multicolumn{1}{c|}{ County } & Fare & Change \% \\
\hline Stockholm & 5.15 & 70 & Älvsborg & 5.1 & 11 \\
\hline Uppland & 8.93 & 87 & Skaraborg* & 4.58 & 32 \\
\hline Södermanland & 8.95 & 92 & Värmland & 5.61 & 29 \\
\hline Östergötland & 4.88 & 6 & Örebro & 5.94 & 36 \\
\hline Jönköping & 6.91 & 87 & Västmanland & 6.88 & 84 \\
\hline Kronoberg & 5.81 & 57 & Dalarna & 4.53 & 50 \\
\hline Kalmar & 11.63 & 200 & Gävleborg & 4.45 & -8 \\
\hline Gotland & 4.62 & 103 & Västernorrland & 5.51 & -73 \\
\hline Blekinge & 7.02 & -66 & Jämtland & 4.55 & 251 \\
\hline Kristianstad* $^{*}$ & 3.88 & 3 & Västerbotten & 8 & 32 \\
\hline Malmöhus & 5.51 & 94 & Norrbotten & 7.38 & 54 \\
\hline Halland $^{*}$ & 7.3 & 129 & Skåne & 6.69 & -29 \\
\hline Göteborg/Bohus $^{*}$ & 3.52 & 23 & Västra Götaland & 6.48 & -13 \\
\hline
\end{tabular}

* In 1997, the Skåne and Västra Götaland regions were formed, the former from Kristianstad and Malmöhus and the latter from Göteborg/Bohus, Älvsborg, and Skaraborg. The figures for these counties therefore cover the years 1986-1997, while the figures for Skåne and Västra Götaland cover the years 1999-2001. 
Table 4. Average level of car ownership and income for the 1986-2001 period in Swedish counties.

\begin{tabular}{|l|c|l|l|c|c|}
\hline \multicolumn{1}{|c|}{ County } & $\begin{array}{c}\text { Cars per } \\
\text { capita }\end{array}$ & $\begin{array}{c}\text { Income } \\
\text { (SEK) }\end{array}$ & \multicolumn{1}{|c|}{ County } & $\begin{array}{c}\text { Cars per } \\
\text { capita }\end{array}$ & $\begin{array}{c}\text { Income } \\
\text { (SEK) }\end{array}$ \\
\hline Stockholm & 0.36 & 188,178 Älvsborg & 0.44 & 152,975 \\
\hline Uppland & 0.40 & 162,020 & Skaraborg* & 0.45 & 146,255 \\
\hline Södermanland & 0.43 & 157,308 Värmland & 0.47 & 152,109 \\
\hline Östergötland & 0.41 & 154,820 Örebro & 0.43 & 155,988 \\
\hline Jönköping & 0.43 & 154,211 Västmanland & 0.42 & 160,102 \\
\hline Kronoberg & 0.45 & 152,364 Dalarna & 0.47 & 153,376 \\
\hline Kalmar & 0.44 & 147,969 Gävleborg & 0.44 & 154,245 \\
\hline Gotland & 0.47 & 140,383 Västernorrland & 0.46 & 158,264 \\
\hline Blekinge & 0.45 & 152,459 Jämtland & 0.44 & 142,917 \\
\hline Kristianstad $^{*}$ & 0.46 & 146,172 Västerbotten & 0.43 & 154,645 \\
\hline Malmöhus & 0.40 & 154,869 & Norrbotten & 0.47 & 159,869 \\
\hline Halland & 0.46 & 157,796 Skåne & 0.45 & 167,472 \\
\hline Göteborg/Bohus $^{*}$ & 0.38 & 160,111 Västra Götaland & 0.44 & 174,164 \\
\hline
\end{tabular}

* In 1997, the Skåne and Västra Götaland regions were formed, the former from Kristianstad and Malmöhus and the latter from Göteborg/Bohus, Älvsborg, and Skaraborg. The figures for these counties therefore cover the years 1986-1997, while the figures from Skåne and Västra Götaland cover the years 1999-2001. 
Table 5.

Results of estimating the demand model (7).

\begin{tabular}{|l|c|c|}
\hline Variable & Coefficient & Standard error \\
\hline Fare & $-6.28^{* * *}$ & 0.46 \\
\hline $\ln (\mathrm{V} / \mathrm{A})$ & $0.65^{* * *}$ & 0.078 \\
\hline $\ln \mathrm{B}$ & $-1.38^{* * *}$ & 0.22 \\
\hline $\ln \mathrm{Y}$ & $0.73^{* * *}$ & 0.069 \\
\hline \multicolumn{2}{|c|}{$* * *=$ significance at the 1\% level }
\end{tabular}


Table 6. Deviation from optimal fare in percent.

\begin{tabular}{|l|c|l|c|}
\hline \multicolumn{1}{|c|}{ County } & $\frac{F-F^{\text {opt }}}{F^{\text {opt }}} \cdot 100$ & \multicolumn{1}{c|}{ County } & $\frac{F-F^{\text {opt }}}{F^{\text {opt }}} \cdot 100$ \\
\hline Stockholm & 35 & Älvsborg & 33 \\
\hline Uppland & 44 & Skaraborg & 11 \\
\hline Södermanland & 60 & Värmland & 29 \\
\hline Östergötland & 9 & Örebro & 18 \\
\hline Jönköping & 23 & Västmanland & 36 \\
\hline Kronoberg & 12 & Dalarna & 11 \\
\hline Kalmar & 215 & Gävleborg & 46 \\
\hline Gotland & 73 & Västernorrland & 54 \\
\hline Blekinge & 43 & Jämtland & 1 \\
\hline Kristianstad & -4 & Västerbotten & 47 \\
\hline Malmöhus & 34 & Norrbotten & 112 \\
\hline Halland & 47 & Skåne & 6 \\
\hline Göteborg/Bohus & 2 & Västra Götaland & 0 \\
\hline
\end{tabular}


Table 7. Fares (nominal) in 2001, calculated optimum and recommended change.

\begin{tabular}{|l|c|c|c|}
\hline \multicolumn{1}{|c|}{ County } & Fare 2001 & Optimal fare 2001 & Recommended change (\%) \\
\hline Stockholm & 7.43 & 6.16 & -17 \\
\hline Uppland & 9.5 & 6.64 & -30 \\
\hline Södermanland & 10.1 & 7.68 & -24 \\
\hline Östergötland & 4.43 & 5.38 & 21 \\
\hline Jönköping & 9.82 & 6.39 & -35 \\
\hline Kronoberg & 7.08 & 8.42 & 19 \\
\hline Kalmar & 19.36 & 3.89 & -80 \\
\hline Gotland & 7.2 & 3.52 & -51 \\
\hline Blekinge & 2.97 & 4.08 & 37 \\
\hline Halland & 10.19 & 7.46 & -27 \\
\hline Värmland & 6.51 & 5.4 & -17 \\
\hline Örebro & 6.7 & 6.54 & -2 \\
\hline Västmanland & 9.52 & 6.94 & -27 \\
\hline Dalarna & 6.02 & 5.28 & -12 \\
\hline Västernorrland & 1.84 & 2.73 & 48 \\
\hline Västerbotten & 8.85 & 6.33 & -28 \\
\hline Norrbotten & 8.9 & 4.13 & -54 \\
\hline Skåne & 5.28 & 6.25 & 18 \\
\hline Västra Götaland & 5.63 & 6.21 & 10 \\
\hline
\end{tabular}


Table 8. Service change due to change in fare under unchanged subsidy.

\begin{tabular}{|l|c|l|c|}
\hline \multicolumn{1}{|c|}{ County } & Service change (\%) & \multicolumn{1}{c|}{ County } & Service change (\%) \\
\hline Stockholm & -8.9 & Värmland & -8 \\
\hline Uppland & -13.2 & Örebro & -1.5 \\
\hline Södermanland & -12.7 & Västmanland & -13 \\
\hline Östergötland & 12.2 & Dalarna & -5.8 \\
\hline Jönköping & -14 & Västernorrland & 13.5 \\
\hline Kronoberg & 18.2 & Västerbotten & -12.8 \\
\hline Kalmar & 8.8 & Norrbotten & -12.9 \\
\hline Gotland & -12.3 & Skåne & 12.1 \\
\hline Blekinge & 16.1 & Västra Götaland & 6.4 \\
\hline Halland & -13.1 & & \\
\hline
\end{tabular}


Table 9. Summary of results of the alterative policy in 2001.

\begin{tabular}{|l|c|c|c|}
\hline \multicolumn{1}{|c|}{ County } & Fare change (\%) & Service change (\%) & Change in number of trips (\%) \\
\hline Stockholm & -17.1 & -8.9 & 2 \\
\hline Uppland & -30.1 & -13.2 & 9.1 \\
\hline Södermanland & -24 & -12.7 & 6.6 \\
\hline Östergötland & 21.4 & 12.2 & 1.5 \\
\hline Jönköping & -34.9 & -14 & 12.7 \\
\hline Kronoberg & 18.9 & 18.2 & 2.4 \\
\hline Kalmar & -79.9 & 8.8 & 178 \\
\hline Gotland & -51 & -12.3 & 15.8 \\
\hline Blekinge & 37.4 & 16.1 & 2.7 \\
\hline Halland & -26.8 & -13.1 & 8.4 \\
\hline Värmland & -17.1 & -8 & 1.6 \\
\hline Örebro & -2.4 & -1.5 & 0.04 \\
\hline Västmanland & -27.1 & -13 & 7.5 \\
\hline Dalarna & -12.3 & -5.8 & 0.8 \\
\hline Västernorrland & 48.4 & 13.5 & 2.7 \\
\hline Västerbotten & -28.5 & -12.8 & 7.2 \\
\hline Norrbotten & -53.6 & -12.9 & 23.6 \\
\hline Skåne & 18.4 & 12.1 & 1.4 \\
\hline Västra Götaland & 10.3 & 6.4 & 0.5 \\
\hline
\end{tabular}

